\title{
MORALITY AND WAR: CAN WAR BE JUST IN THE TWENTY-FIRST CENTURY?
}

\section{David Fisher}

Oxford University Press

2011

ISBN: 0199599246

320 pages

\$45.00 (amazon.com) / R546 (kalahari.com)

While contemporary wars are trending away from conventional methods and governments are faced with increasingly difficult decisions about how to wage war, Fisher declares nonetheless that the just war tradition continues to offer a valid standard for determining the moral justification of acts of war. Fisher declares the aim of his book to be -

... to establish a framework for moral reasoning, based on the just war tradition, that is imbued with rather more practical wisdom than that of the realist caricature, and that can offer guidance both to policy-makers and ordinary service people in considering questions of war and peace. ${ }^{1}$

Fisher brings a valuable applied perspective to the philosophy concerned with the morality of warfare, because, as an experienced senior civil servant and government adviser, he has first-hand experience of the policy impact of the philosophical ideas addressed in this book.

At the conceptual level, Fisher recognises the importance of different streams of thought in moral philosophy, specifically absolutism, virtue ethics, and consequentialism, but critiques each of them for over-emphasising only one element of morality. Arguing that humanity and the world are too complex to be addressed by an approach to morality that is tied to any one of these streams, he advocates his own alternative, virtuous consequentialism, which draws from each of them and makes practical wisdom the central guide in moral decision-making.

Scientia Militaria, South African Journal of Military Studies, Vol 40, Nr 2, 2012, pp. 174-179 doi: $10.5787 / 40-2-1004$
Claiming to account for the complexity of decision-making as no other system does, Fisher's virtuous consequentialism considers the mental state of 
the actor, moral principles, the guiding influence of virtues, the act itself, and the consequences. Fisher's approach leans most heavily towards virtue theory, which makes for an interesting counterpoint to Brian Orend's War and international justice: A Kantian perspective (2000). ${ }^{2}$ Orend's Kantian approach falls into what Fisher calls an absolutist approach to morality, which he (Fisher) appreciates but ultimately rejects, claiming that absolutism has the potential for unintuitive results through its refusal to consider only the actor's intentions. Aristotle defined practical wisdom, the essential element of Fisher's system of moral philosophy, as "correct deliberation about what serves an end" and "the ability to reach sound conclusions about ... what conduces to the good life as a whole". ${ }^{3}$ Fisher emphasises this second aspect of practical wisdom as the basis for judging an act's morality. The ancient Greeks sought the good life, this human flourishing or eudemonia, through practicing virtue; modern man is no different. Virtuous actions contribute to the well-being of society and provide mutual benefit. Consequently, Fisher judges every action by its effect on human flourishing, both by its influence on the character of the actor and by its impact on the larger community.

Fisher tackles the same problem as many other philosophers, namely how to extend morality from the private realm to the international scene, by arguing that these levels present only a difference of degree, not of principle. He advocates national morality at an individual level, remarking numerous times on the importance of training even the lowest private soldier in the virtues, because of the habituation needed to develop virtuous character. Unfortunately, though he pleads with the military to inculcate the virtues which, he argues, society no longer stresses, he offers no guidance for how to achieve that habituation. The classroom is not the right forum; virtue requires repeated action, so military leaders must provide the role model. However, how can one improve the situation when, as Fisher seems to argue, there are not enough role models left? A basis of morality or a quorum of virtuous people seems necessary to support his moral theory of virtuous consequentialism. He rails against the loss of morality but offers no solution to address this issue.

Fisher's approach to morality echoes the Catholic church's doctrine as outlined in the catechism of the Catholic church, which exhorts all people to act virtuously in alignment with a well-formed conscience. Fisher, however, is explicitly and deliberately seeking to develop an approach to the just war tradition that is not tied to religion but which is instead available beyond doctrinal boundaries. Religious morality, Fisher contends, often depends upon inviolable principles, which have an "appealing moral clarity"4 but which frequently conflict in public life and are hard "to reconcile with the harsh realities of daily life". 5 Policy 
makers need a way to determine the moral choice without relying exclusively on religious principles and without turning to realism.

Fisher rightly condemns the realist approach for excluding morality from war by claiming, "war is cruelty and you cannot refine it". 6 A more sophisticated realism would recognise that, in modern warfare, "ethical restraint may be necessary to the strategic success of military campaigns" "7 as demonstrated in America's strategy of winning hearts and minds to resolve the turmoil in Iraq. ${ }^{8}$ He focuses on non-combatant immunity, an issue that has steadily garnered more attention as nonstate actors are engaging in warfare within urban environments, and the civilian casualty rate has skyrocketed. In his discussion of the doctrine of double effect (DDE), Fisher shows that this decision-making framework is inevitably subjective, but argues that it nonetheless provides a valuable concept to help us think through the issues involved, even though we may not apply it. The DDE could be used to justify a wide array of actions, depending upon one's definition of "intended" and other such words, and remains unable to strictly account for the nuances of the decision-making process. Its most common usage is analysing the morality of actions that will cause civilian deaths in pursuit of a military target. By the necessity of warfare, non-combatant immunity cannot be absolute, for then almost no military operations could occur, but every effort should "be made to minimise civilian casualties, whether intended or foreseen". ${ }^{9}$ As numerous nations at war have again discovered, civilian deaths can alienate the population and decrease their support for a foreign presence.

Morality and war offers the reader a well-considered argument for the relevance of just war tradition as a codification of centuries of practical wisdom, and for the importance of morality in promoting a better human society. Fisher avoids overly technical language, carefully defining and explaining his terms in order to make the material comprehensible to any reader. However, in making abstract ideas such as the just war tradition accessible to the common reader, he loses some of the philosophical rigor one would expect. The book covers important ground, addressing key contemporary issues that are central to the just war debate. Among other things, Fisher offers an extended analysis of the Gulf wars, discusses humanitarian intervention as necessary but generally not permitted by international laws which still conform to the ideology of the Treaty of Westphalia, and considers the morality of torture and interrogation.

Perhaps the weakest part of the book is that aspect thereof that was potentially the most interesting. Fisher's theory of virtuous consequentialism is, in 
the end, underdeveloped and difficult to distinguish in its application from mere intuitionism (mostly in the guise of 'practical wisdom'). The elements of the just war tradition have been accumulated as men and women of conscience analyse the wars of their times, determine their moral justification, and define which elements of war-fighting contribute to that justification. We must continue to analyse the wars of our time to perpetuate this important ethical tradition and to guide governments and policy makers in their decision-making process. Virtuous consequentialism outlines the aspects of a decision that one should consider, but ultimately it is unconvincing in its implied hope that natural law and society have formed our consciences well enough that we can judge the good intuitively.

Erica Leinmiller

United States Naval Academy

${ }^{1}$ Fisher, D, Morality and War: Can War be Just in the Twenty-First Century?, Oxford: Oxford University Press, 2011, p. 22.

${ }^{2}$ Orend, B, War and International Justice: A Kantian perspective, Waterloo:

Ontario, Wilfrid Laurier University Press, 2000.

${ }^{3}$ Fisher, op. cit., p. 52.

${ }^{4}$ Ibid., pp. 64.

${ }^{5}$ Ibid., pp. 64.

${ }^{6}$ Ibid., pp. 25

${ }^{7}$ Ibid., pp. 27

${ }^{8}$ Ibid., pp. 27.

${ }^{9}$ Ibid., pp. 101. 